\title{
IMPACT OF UNIVERSITY COMMITMENT AND STUDENT AMBITION ON GRADUATE EMPLOYABILITY: A STUDY ON SELECTED PRIVATE UNIVERSITIES IN SYLHET
}

\author{
Md. Abdul Muhith Chowdhury \\ Assistant Professor \\ Department of Business Administration \\ Leading University, Ragibnagar, Sylhet, Bangladesh \\ E-mail: muhith@lus.ac.bd
}

\begin{abstract}
There is a growing concern in the areas of employability that has increased in the last few decades due to the increased growth process and global competition. This study is based on identifying the impact of university commitment and student ambition on graduate employability. The research aimed to investigate the job market scenario in Bangladesh by reviewing the literature and provide suggestions to different stakeholders of employability. In total, the sample comprises 100 responses from students who are in their final year of study. Different international and local studies on this topic have been reviewed, and a structured questionnaire was used for collecting data from the respondents. The multiple Linear Regression method was used to analyze the data statistically. The result indicates that a one percent increase in the commitment by the university will increase graduate employability by 45 percent, while a one percent rise in student ambition will help to rise graduate employability by 31 percent.
\end{abstract}

Keywords: Graduate, Labor Market, Employability, University, Commitment, Ambition.

\section{INTRODUCTION}

Though employability was once seen as a western concept, nowadays it is essential for the underdeveloped and developing countries for their sustainability. The concept of employability can be viewed from the perspectives of the workforce, as a Human Resource Strategy, and perspectives of Individuals (Rothwell et al., 2008). Behle and Atfield (2013) identified that students' perception of employability often differs from the perception of employers. The students need to understand the concept of self-perceived employability for devising overall career development (Redmond, 2010). Employability can be measured as a 'psycho-social construct' that helps individuals to cope up in a rapidly changing environment. The first part of this paper sets the context of the study by stating the problem and reviewing appropriate literature; followed by the next part as the development of objectives and setting the hypothesis. Afterward, the research methodology section states the research design and data analysis tools, and based on that analysis was done. Lastly, the concluding remarks have been drawn.

\section{LITERATURE REVIEW}

The graduates need to understand the concept of self-perceived employability for overall career development and management (Redmond, 2010). There is a lack of research that has been done in Bangladesh to identify what it takes to make the graduates more employable (Chisty et al., 2007). The university education system in Bangladesh has faced a dramatic change for so many years because of political turmoil in public universities, and a quest for good quality by private institutions (Ahmed \& Crossman, 2014). The youth unemployment rate has been doubled with a limited period of only 7 years between the years 2010 to 2017 (Chowdhury, 2020). All the 
stakeholders (policymakers, HEIs, and universities) need to take appropriate action to enhance the employability of graduates.

\section{PROBLEM STATEMENT}

Graduate employability and overall employment levels that exist throughout the country are a matter of growing concern for the Government and policymakers in Bangladesh. The labor market in Bangladesh is still not being able to produce skilled manpower as per the expectation of the employers. The issue of employability should be considered with the highest priority by all stakeholders involved for their existence. There is still a mismatch in the unemployment and underemployment situation in Bangladesh. The present study aimed at highlighting the following questions: What extent of the effect the university commitment and student ambition have on the employability of graduates from the viewpoints of graduates.

\section{OBJECTIVES OF THE RESEARCH}

The main objective of this research paper is to analyze the impact of university commitment and student ambition on the employability of graduates. However, the specific objectives are to explore the following aspects:

- To identify the problems in the job market in Bangladesh in relation to employability.

- To highlight the implications of this research for future policy development.

\section{HYPOTHESIS DEVELOPMENT}

With a view of fulfilling the objectives, two relevant hypotheses have been developed for this study:

- $\mathrm{H}_{1}$ : University commitment has a significant positive impact on graduate employability.

- $\mathrm{H}_{2}$ : Ambition of the Student has a significant positive impact on graduate employability.

\section{RESEARCH METHODOLOGY}

The study is empirical in nature where the convenience-sampling method has been used to collect responses from 100 students from four private universities in the Sylhet region of Bangladesh by using a structured questionnaire. The study used the employability scale developed by Rothwell et al. (2008) which covered 30 variables some of which were adapted from other studies in employability. Variables were measured on a 5-point Likert scale (1=strongly disagree to $5=$ strongly agree). Multiple regression analysis was done to test the hypothesis. A series of tests was conducted beforehand to authenticate the appropriateness of using regression analysis.

\section{RESULTS AND DISCUSSION}

The skewness and kurtosis of the dependant variable Graduate Employability were -.588 (S.E=.24) and .670 (S.E=.47) respectively. From the matrix scatterplot, it was evident that a linear relationship exists among the dependant variable (Graduate Employability) with the independent variables. Then, the scatterplot between Regression Standardized Residual and Regression Standardized Predicted Values (shown in the appendix) proved the Non-violation of Homoscedasticity (Pryce, 2002). With a Tolerance value of .870 (>.1) and VIF $1.150(<10)$, multicollinearity was approved (Hills \& Adkins, 2001).

Table 1. Summary

\begin{tabular}{|l|l|l|l|l|}
\hline Hypothesis & Statements & $\begin{array}{l}\text { Standardized } \\
\text { Coefficients }\end{array}$ & Significance & Result \\
\hline $\mathrm{H}_{1}$ & $\begin{array}{l}\text { The commitment of the University has a positive significant impact on Graduate } \\
\text { Employability }\end{array}$ \\
\hline
\end{tabular}




\begin{tabular}{|c|c|c|c|c|}
\hline & $\begin{array}{l}\text { University Commitment - } \\
\text { > Graduate Employability }\end{array}$ & .451 & .000 & Accepted \\
\hline \multirow[t]{2}{*}{$\mathrm{H}_{2}$} & \multicolumn{4}{|c|}{$\begin{array}{l}\text { The ambition of the Student has a positive significant impact on Graduate } \\
\text { Employability }\end{array}$} \\
\hline & $\begin{array}{l}\text { Student Ambition -> } \\
\text { Graduate Employability }\end{array}$ & .313 & .000 & Accepted \\
\hline
\end{tabular}

From the result of the regression it is evident that university commitment and student ambition explained $39.1 \%$ of the variance in the employability of the graduates $\left(\mathrm{R}^{2}=.391\right.$, $\mathrm{F}(2,97)=32.84, \mathrm{p}<.001)$. University commitment has a significant impact on the employability of graduates $(\beta=.45, \mathrm{p}<.001)$. Likewise, there is also a significant influence of student ambition on graduate employability $(\beta=.31, \mathrm{p}<.001)$.

The result indicates that a one percent increase in the commitment by the university will increase graduate employability by 45 percent, and likewise, a one percent rise in the student ambition will increase graduate employability by 31 percent.

\section{CONCLUSION}

This study has the potential for contributing to further research in the areas of university commitment, student ambition, and graduate employability. The collaborative view of graduates, Government policymakers, HEIs, and employers should be sought together for augmenting employability in general. Government policymakers, academicians, universities, and business organizations should work collaboratively. The HEIs should offer work-oriented courses to orient their graduates in a competitive job market. They should design their course curriculum based on industry needs by emphasizing fieldwork, job shadowing, case studies, presentation skills, and group discussion. They can also introduce short courses on ICT knowledge, English, and communication skills. The universities should encourage students to participate in extracurricular activities, which results in the development of self-employability. The existing gap between study and employment can be minimized through employer engagement in education, training, and course content development. The government should upgrade education policy based on international benchmarking of competency-based curricula.

\section{REFERENCES}

Ahmed, R., \& Crossman, J. (2014). Significance of Employability Factors: Bangladesh Perspectives. Retrieved from http://www.researhgate.net/publication/228597908

Behle, H., \& Atfield, G. (2013). Employability, Key Skills and graduate attributes The Global Student Experience: An International and Comparative Analysis. C. Kandiko and M. Weyers. Oxon and New York.

Chisty, K. K. S., Uddin, G. M., \& Ghosh, S. K. (2007). The business graduate employability in Bangladesh: Dilemma and expected skills by corporate world, Brac University Journal, IV(1), 1-8.

Chowdhury, F. (2020). Work Integrated Learning at Tertiary Level to Enhance Graduate Employability in Bangladesh. International Journal of Higher Education, 9(4), 61-68.

Hill, R. C., \& Adkins, L. C. (2001). Collinearity. A companion to theoretical econometrics, $257-$ 78.

Pryce, G. (2002). Heteroscedasticity: Testing and correcting in SPSS. University of Glasgow. 
Redmond, P. (2010). The graduate jobs handbook: how to land your dream career. Trotman.

Rothwell, A., Herbert, I., \& Rothwell, F. (2008). Self-perceived employability: Construction and initial validation of a scale for university students. Journal of vocational behavior, 73(1), $1-12$.

Rothwell, A., Jewell, S., \& Hardie, M. (2009). Self-perceived employability: Investigating the responses of post-graduate students. Journal of vocational behavior, 75(2), 152-161.

\section{APPENDICES}

\section{Appendix A. Figure 1. Histogram and Normal Q-Q Plot of Graduate Employability}
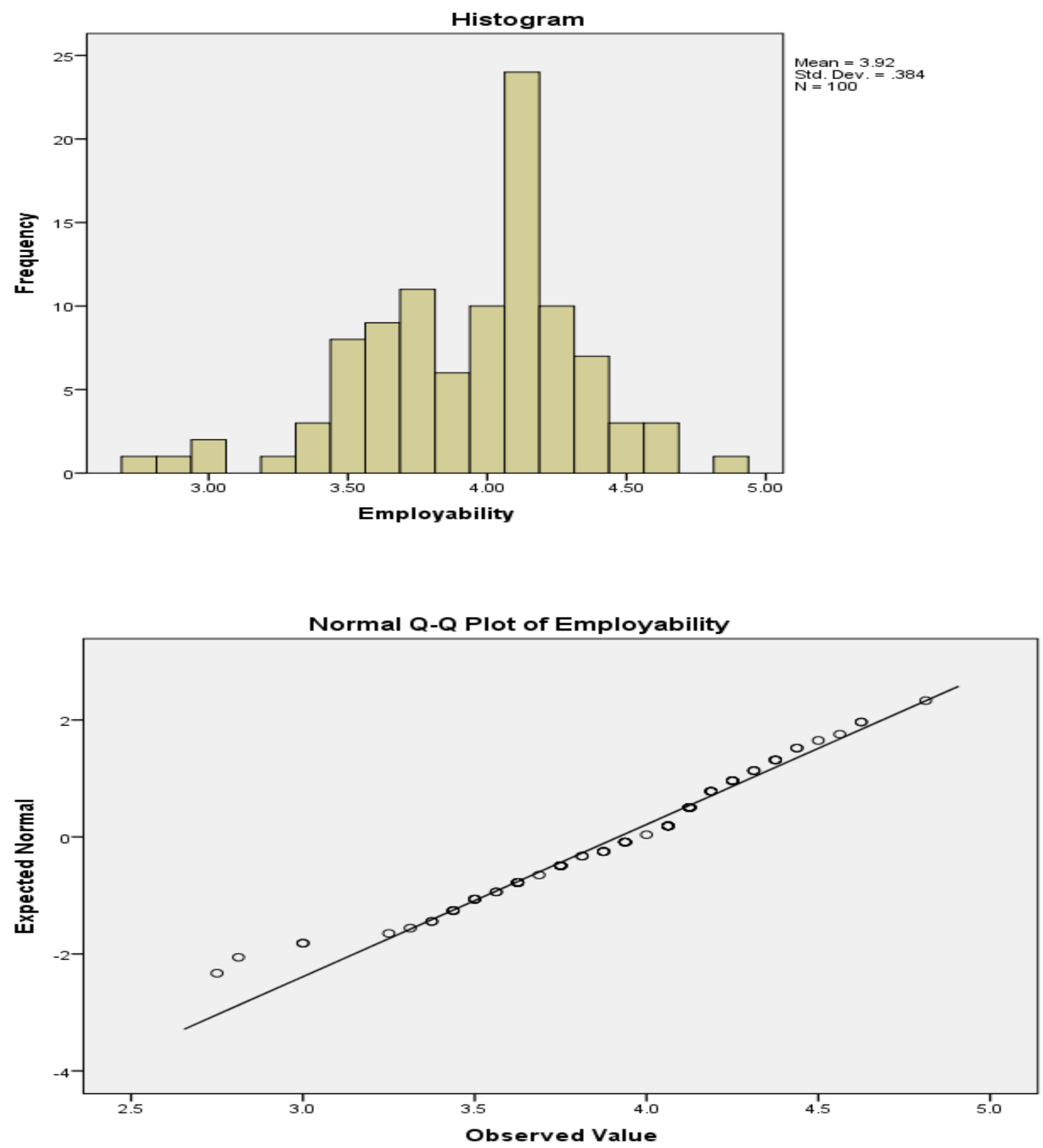

Data Extracted from SPSS 


\section{Appendix B. Figure 2. Histogram and Normal Q-Q Plot of University Commitment}
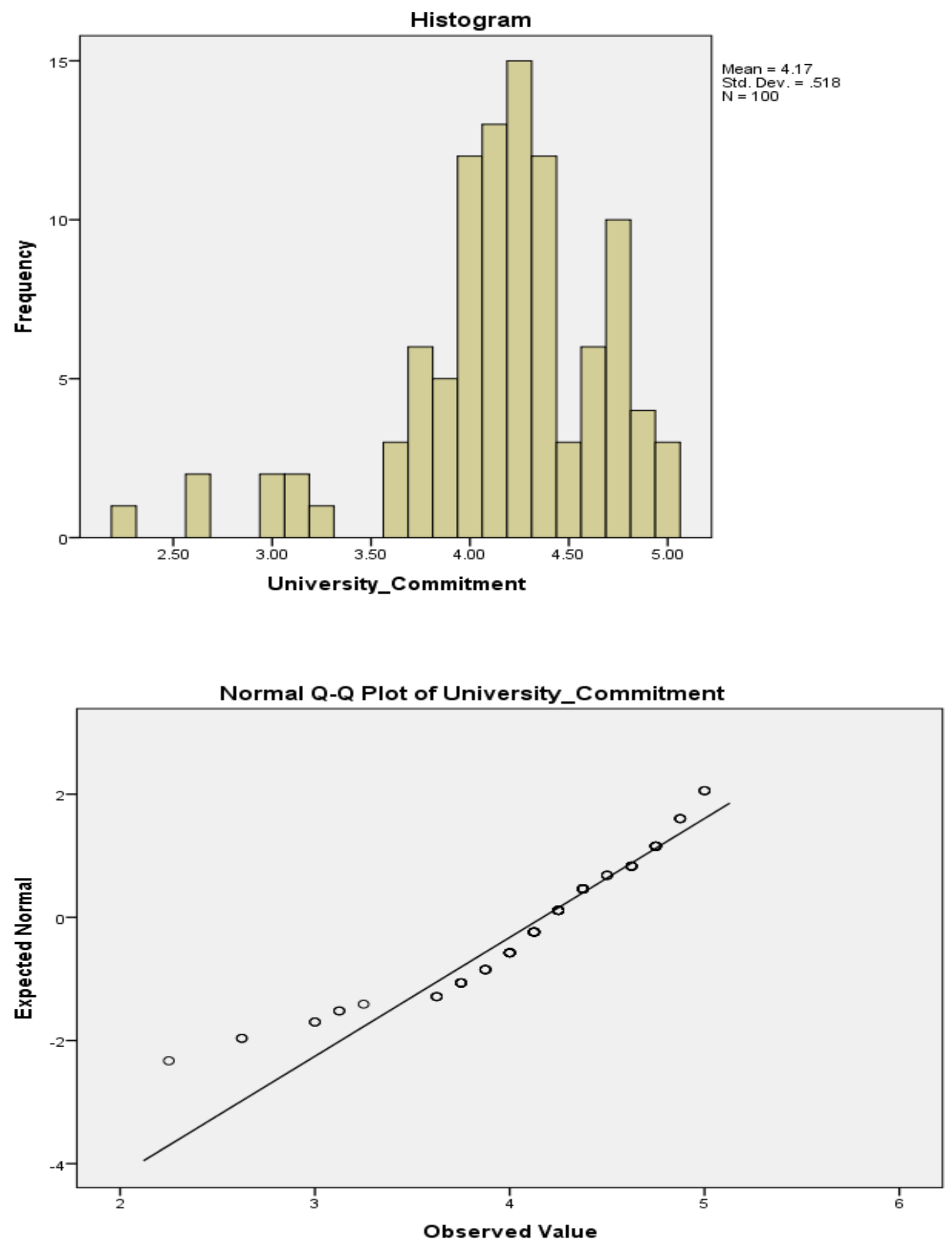

Data Extracted from SPSS 


\section{Appendix C. Figure 3. Histogram and Normal Q-Q Plot of Student Ambition}
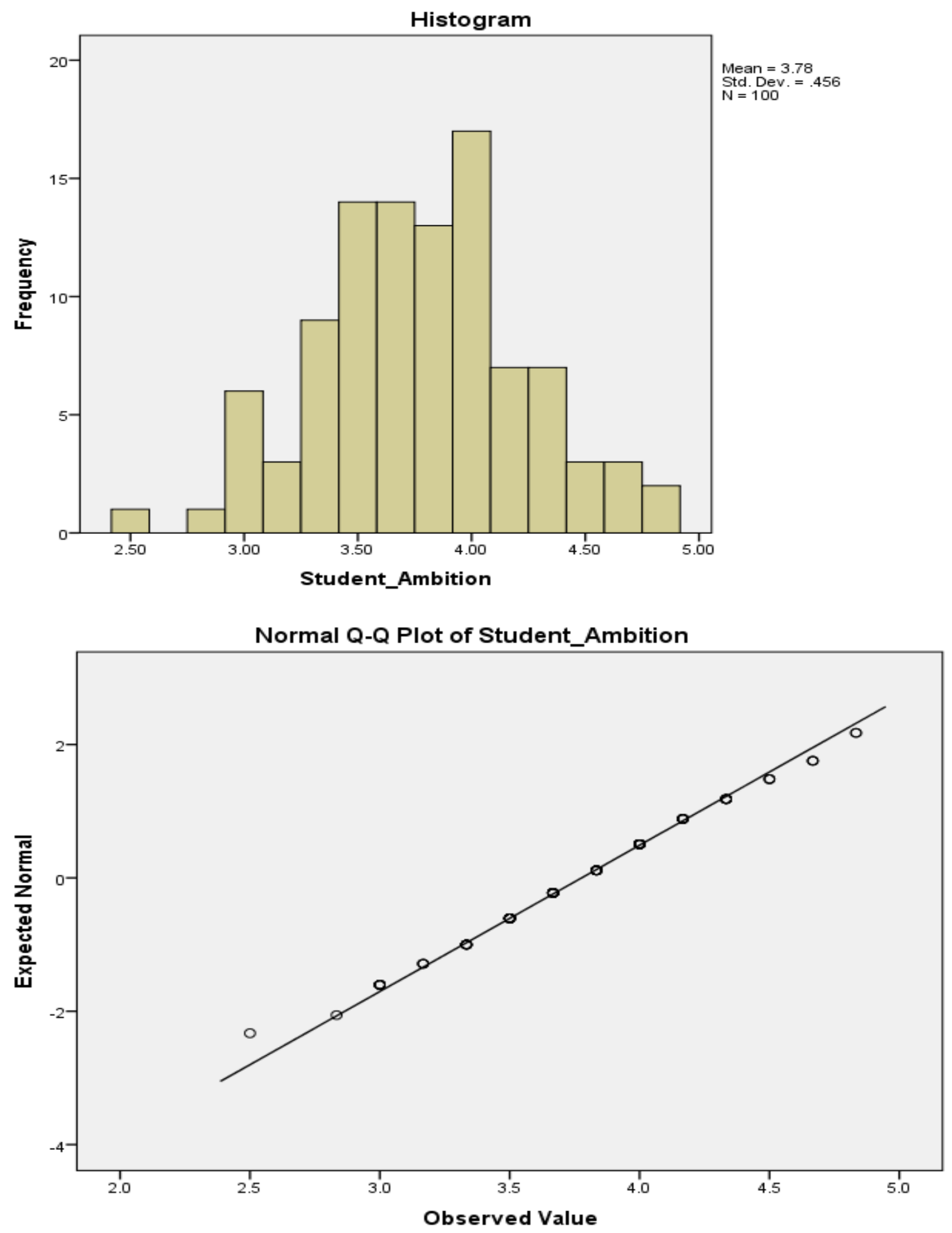

Data Extracted from SPSS 
Appendix D. Figure 4. Correlations

\begin{tabular}{|c|c|c|c|c|}
\hline \multicolumn{5}{|c|}{ Correlations } \\
\hline & & $\begin{array}{c}\text { Employabil } \\
\text { ity }\end{array}$ & $\begin{array}{c}\text { Student } \\
\text { Ambition }\end{array}$ & $\begin{array}{c}\text { University } \\
\text { Commitment }\end{array}$ \\
\hline \multirow{3}{*}{$\begin{array}{l}\text { Pearson } \\
\text { Correlation }\end{array}$} & Employability & 1.000 & .476 & .564 \\
\hline & Student Ambition & .476 & 1.000 & .361 \\
\hline & $\begin{array}{l}\text { University } \\
\text { Commitment }\end{array}$ & .564 & .361 & 1.000 \\
\hline \multirow[t]{3}{*}{ Sig. (1-tailed) } & Employability & & .000 & .000 \\
\hline & Student Ambition & .000 & & .000 \\
\hline & $\begin{array}{l}\text { University } \\
\text { Commitment }\end{array}$ & .000 & .000 & \\
\hline \multirow[t]{3}{*}{$\mathrm{N}$} & Employability & 100 & 100 & 100 \\
\hline & Student Ambition & 100 & 100 & 100 \\
\hline & $\begin{array}{l}\text { University } \\
\text { Commitment }\end{array}$ & 100 & 100 & 100 \\
\hline
\end{tabular}

Data Extracted from SPSS

Appendix E. Figure 5. Scatterplot between the Regression Standardized Residual and Regression Standardized Predicted Value

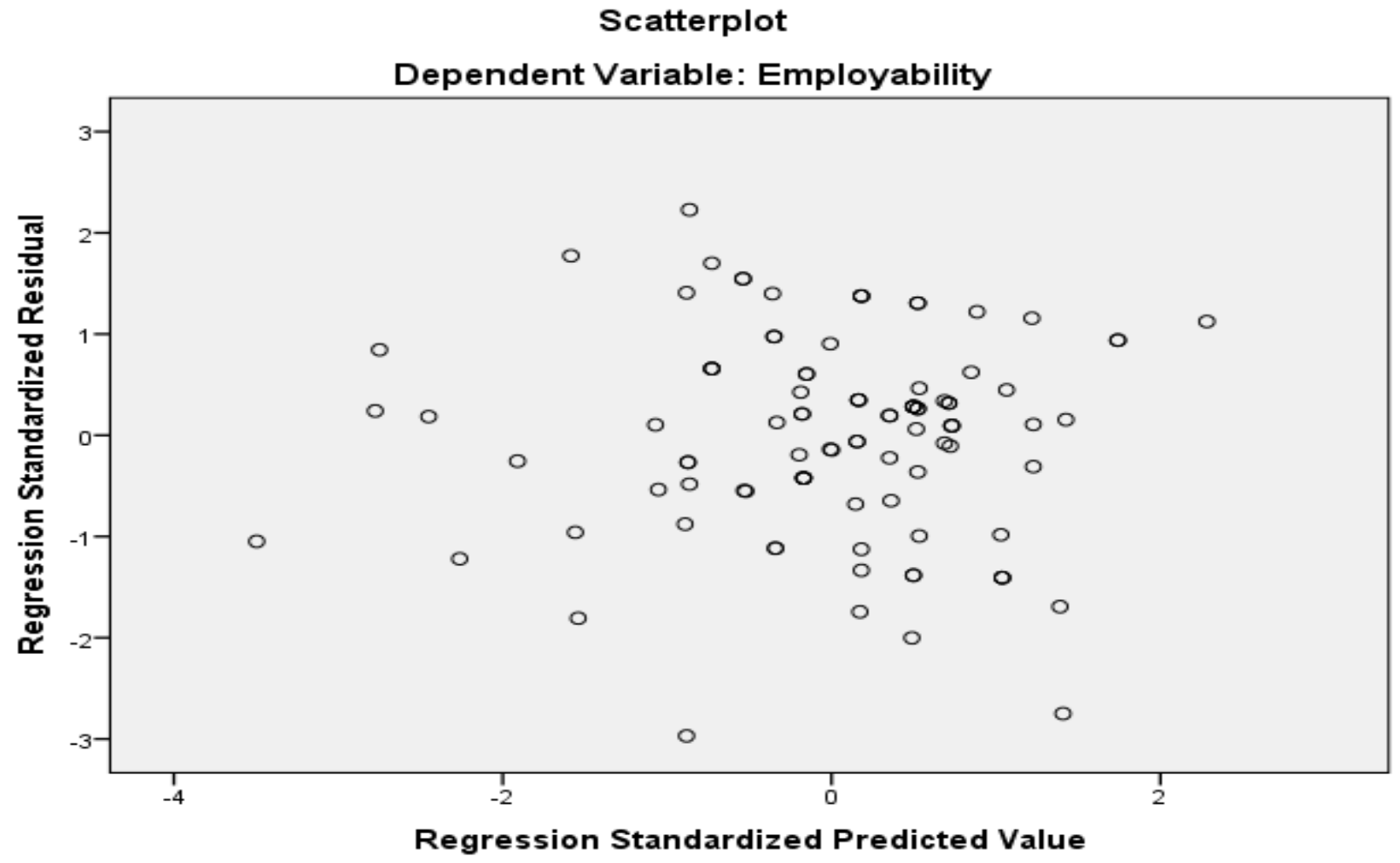

Data Extracted from SPSS

\section{Copyrights}

Copyright for this article is retained by the author(s), with first publication rights granted to the journal. This is an open-access article distributed under the terms and conditions of the Creative Commons Attribution license (http://creativecommons.org/licenses/by/4.0/) 